\title{
BENZOIC ACID DERIVATIVE IN THE SECRETA OF THE GENITAL EPITHELIUM OF THE COW
}

\author{
SUSAN N. GÁSPÁR ANd A. GSEH \\ Physiological Department, Veterinary Faculty, University of Budapest, Budapest VII, \\ Hungary
}

(Received 9th May 1963)

The secretion of citric acid by the bovine female genital epithelium has been investigated by Gáspár \& Cseh (1963). In $60 \%$ of cases no citric acid was present, but in the secreta of $40 \%$ of the cows, quantities corresponding to spots of 1.5 to $40 \mu \mathrm{g}$ could be demonstrated. In $30 \%$ of the investigated cases one unidentified spot, usually accompanied by citric acid and showing $R_{\mathbf{f}}$ values from 0.78 to 0.80 , also appeared on the chromatogram. We have been trying to identify more closely the compound forming this spot. It was diffusible and remained unhydrolysed in $1 \mathrm{~N}$-sulphuric acid for $2 \mathrm{hr}$ and was in character acid. Although the unknown compound was generally accompanied by citric acid, it could not be identified either with lactic acid, pyruvic acid and the components of the citrate cycle, or with maleinic and citraconic acid.

Oestrous secreta from eighty-four living dairy cows and sixty slaughtered animals were used as test material. The material from living cows was collected directly from the os of the cervix by aspiration with a syringe provided with a catheter. Uterine mucus, oviduct fluid, and follicular fluid was collected from slaughtered animals directly from the organ. The method of paper chromatography described by Schreier \& Hack (1956) was used. The absorption spectrum of the stained compound, eluted with ethanol, was measured with a Beckman spectrophotometer.

The unknown compound is supposed to be closely related to or even identical with hippuric acid, which is found in exceedingly large quantities in herbivora, as a final product of the detoxication of benzoic acid and its derivates. This conclusion is based on the following considerations. (a) The comparison made between the chromatographic data of Gaffney, Schreier, DiFerrante \& Altman (1954) and our own results (see Table 1). (b) The absorption maximum of the substance tested by Gaffney et al. (1954) was at $460 \mathrm{m \mu}$, while that of the substance deriving from the secreta and the absorption maximum of hippuric acid under similar conditions were found at $475 \mathrm{m \mu}$ (see Gaffney et al. Fig. 1 and Text-figs. 1 and 2). (c) In-vivo load tests also prove that the investigated substance is a benzoic acid derivative. Sixty to $90 \mathrm{mg} / \mathrm{kg}$ of sodium benzoate was administered intravenously to five cows. The substance tentatively identified as 
TABLE 1

SUMMARY OF THE DATA OBTAINED BY GHROMATOGRAPHIC SEPARATION

\begin{tabular}{l|l|c|c|c}
\hline \multicolumn{1}{c|}{ Compound } & \multicolumn{1}{|c|}{ Solvent } & Filter paper & $\begin{array}{c}\text { Solvent } \\
\text { front } \\
(\mathrm{cm})\end{array}$ & $R_{f}$ value \\
\hline $\begin{array}{l}\text { Hippuric acid } \\
\text { (Gaffney et al., 1954) }\end{array}$ & $\begin{array}{l}\text { Butanol-acetic acid- } \\
\text { water } \\
4: 1: 1\end{array}$ & Whatman No. 1 & 30 & 0.81 \\
\hline $\begin{array}{l}\text { Hippuric acid } \\
\text { (own system) }\end{array}$ & $\begin{array}{l}\text { Butanol-acetic acid- } \\
\text { water } \\
4: 1: 1\end{array}$ & $\begin{array}{l}\text { Macherey-Nagel, } \\
214\end{array}$ & 28 & 0.83 \\
\hline $\begin{array}{l}\text { Hippuric acid } \\
\text { (mixed with genital } \\
\text { secreta) }\end{array}$ & $\begin{array}{l}\text { Butanol-acetic acid- } \\
\text { water } \\
4: 1: 1\end{array}$ & $\begin{array}{l}\text { Macherey-Nagel, } \\
214\end{array}$ & 27 & 0.081 \\
\hline $\begin{array}{l}\text { Acid of unknown com- } \\
\text { position }\end{array}$ & $\begin{array}{l}\text { Butanol-acetic acid- } \\
\text { water } \\
4: 1: 1\end{array}$ & $\begin{array}{l}\text { Macherey-Nagel, } \\
214\end{array}$ & 28 & 0.78 to 0.81 \\
\hline
\end{tabular}

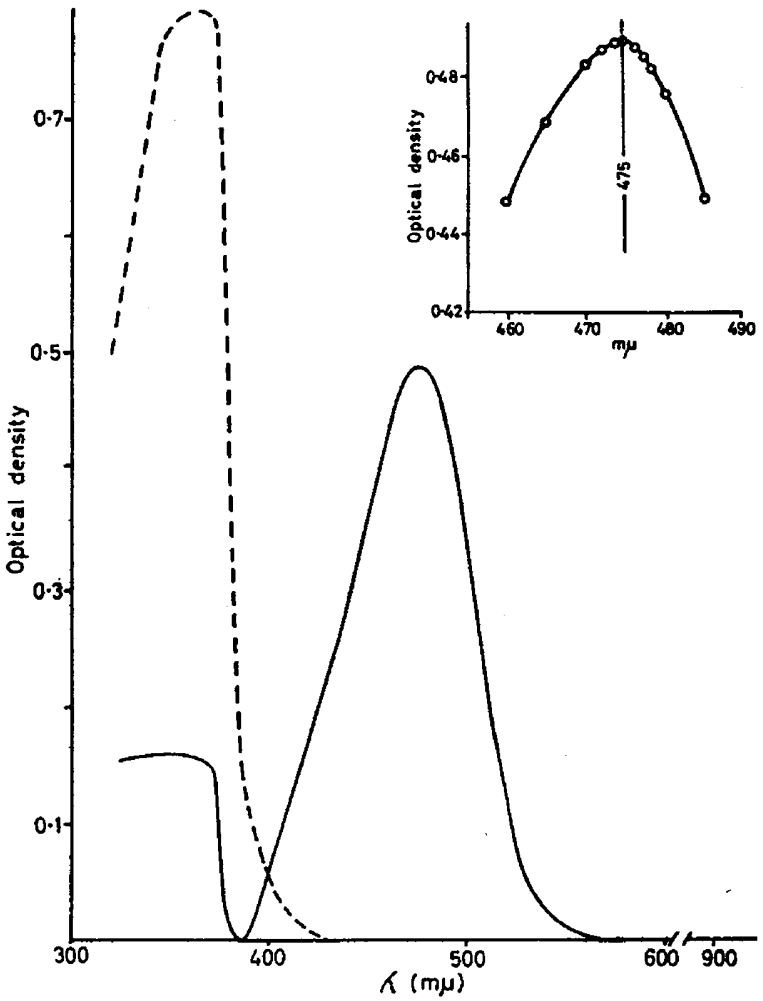

TEXT-RIG. 1. Absorption spectrum of unknown compound. . . . . Absorption spectrum of developing reagent. 
hippuric acid appeared in the secreta of three of them within 18 to $24 \mathrm{hr}$. In the case of the other two cows, however, the substance did not appear in the secreta in spite of repeated infusions with sodium benzoate.

Regarding the biological circumstances of the appearance of hippuric acid in the genital secretion, the following observations were made. (a) Being found in only $30 \%$ of the tested animals, it is not an indispensable ingredient of the oestrous secreta. (b) Its presence is not restricted to the oestrous period, consequently its appearance is not related to oestrogen activity. (c) Its presence was demonstrated not only in the cervico-vaginal fluid of slaughtered cows but also in the secreta of corpus and cornus uteri. Demonstrable quantities were not found, however, in the oviduct fluid, follicular fluid or the deproteinized serum. (d) With greater quantities of hippuric acid in the secreta the chance of success-

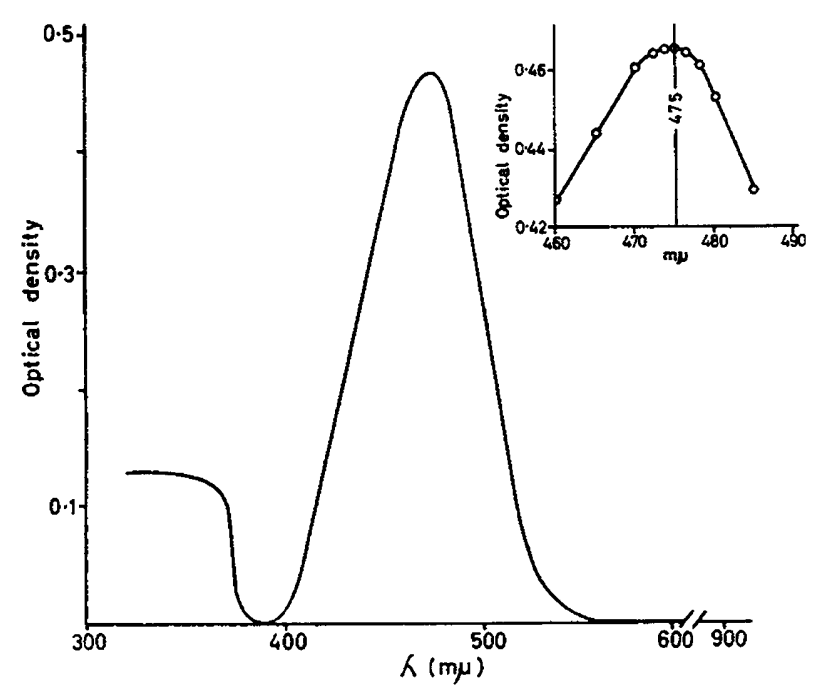

TEXT-FIG. 2. Absorption spectrum of hippuric acid in our system.

ful insemination decreases. The conception ratio of the animals which were positive in this respect was $20 \%$ (four animals out of twenty) against $75 \%$ of the animals which were negative (thirty out of forty). In some cases the animals with hippuric acid in the genital secreta were held under control for a longer period by repeated sampling. There were animals among them which produced hippuric acid-free secreta two or three cycles later. Consequently the presence of hippuric acid in the genital tract should not be considered as the result of special activity characteristic of the genital epithelium of certain animals, but is the result of some yet unknown effect or condition. The same conclusion can be drawn from our in-vivo load tests in which hippuric acid excretion was produced by intravenous administration of sodium benzoate in three cows out of five but not in the other two. 


\section{REFERENCES}

Gaffney, G. W., Schreier, K., Diferrante, N. \& Altmann, K. I. (1954) The quantitative determination of hippuric acid. 7. biol. Chem. 206, 695.

GÁspár, S. N. \& CsEH, A. (1963) Papirkromatográfiás vizsgálatok a szarvasmarha cervico-vaginális szekrtumának folyadékfázisából. Magy. Allotoro. Lap. 18, 32.

SCHREIER, K. \& HACK, W. (1956) UUber einen papierchromatographischen Nachweis von Citronensäure, Aconitinsäure und Weinsäure. Naturwissenschaften, 43, 178. 